\title{
Subungual Molluscum Contagiosum: A Rare Presentation
}

\author{
Ömer Faruk Elmas ${ }^{\mathrm{a}}$ Asuman Kilitçi ${ }^{\mathrm{b}}$ \\ ${ }^{a}$ Department of Dermatology, Ahi Evran University, Kırşehir, Turkey; \\ ${ }^{\mathrm{b}}$ Department of Pathology, Ahi Evran University, Kırşehir, Turkey
}

\section{Established Facts}

- Molluscum contagiosum can affect any site of the body, but the lower abdomen, thighs, genitals, and perianal area are the sites most commonly involved.

- Oral, ocular, and plantar regions are unusual localizations reported for molluscum contagiosum.

\section{Novel Insights}

- MC occur rarely in the subungual area.

- Subungual MC may imitate subungual warts, digital fibrokeratomas, and melanomas.

- Dermoscopy may help to diagnose subungual MC.

\section{Keywords}

Dermoscopy · Molluscum · Nail · Subungual molluscum contagiosum

\begin{abstract}
Molluscum contagiosum (MC) is a self-limiting viral infectious cutaneous disease usually characterized by pinkish skin color and round umbilicated papules varying in size and shape. MC can affect any region, but the lower abdomen, thighs, genitals, and perianal area are the sites most commonly involved. Atypical localizations of the lesions may be difficult to diagnose. We report a case of subungual MC with dermoscopic features in a young male.
\end{abstract}

(c) 2019 S. Karger AG, Basel

\section{KARGER}

() 2019 S. Karger AG, Basel

E-Mail karger@karger.com

www.karger.com/sad

\section{Introduction}

Molluscum contagiosum (MC) is a self-limited, viral, infectious, cutaneous disease caused by the $\mathrm{MC}$ virus that belongs to the Poxviridae family. Sexual or nonsexual direct contact with the infected skin and autoinoculation are the main transmission ways. MC is usually characterized by pinkish to skin color and round umbilicated papules varying in size and shape. The diagnosis is usually based on clinical findings [1]. Here, we report a case of MC with atypical localization, which was initially misdiagnosed as viral wart. 
Fig. 1. a Pinkish papular lesions on the hyponychium. b The same region 3 weeks after treatment.
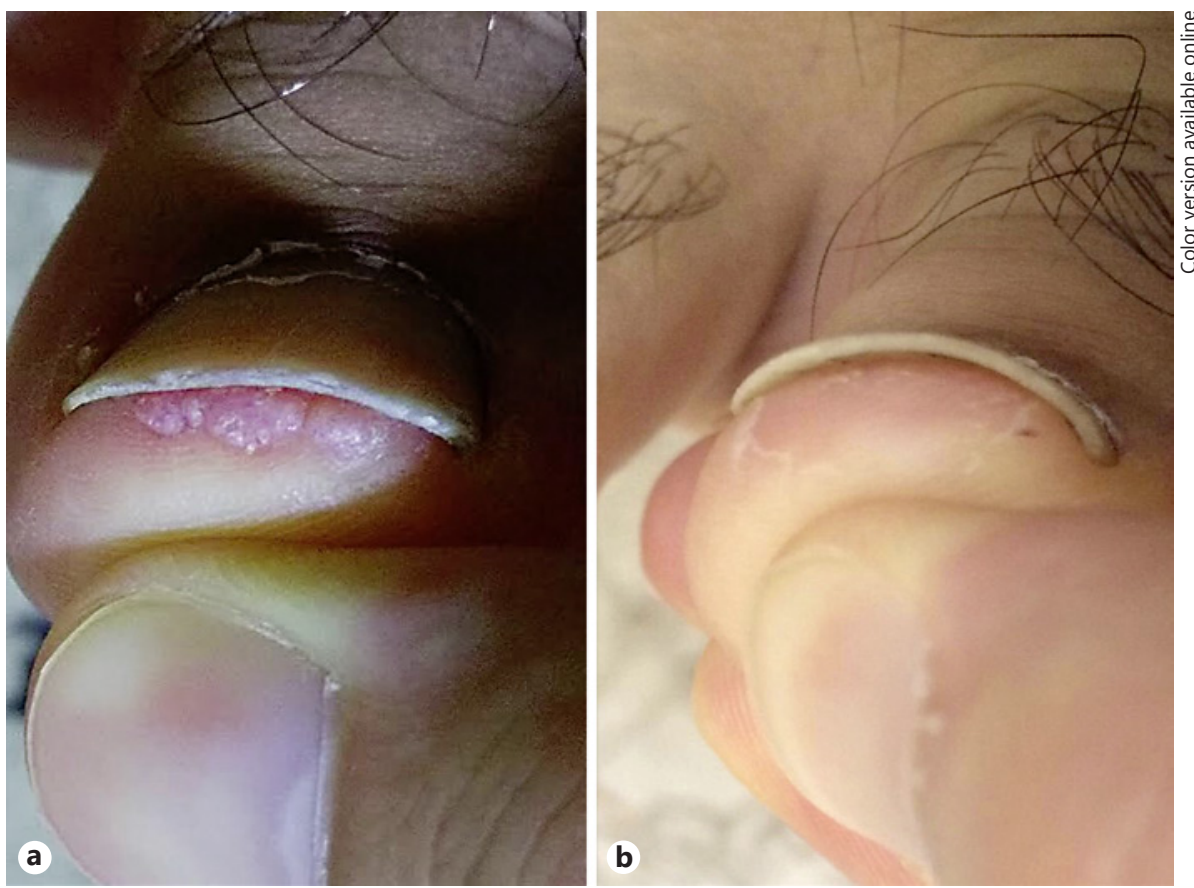

2

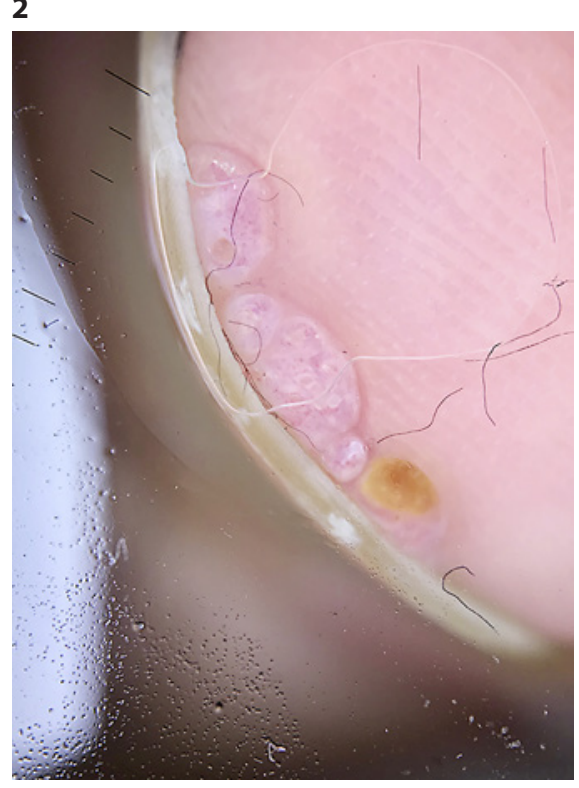

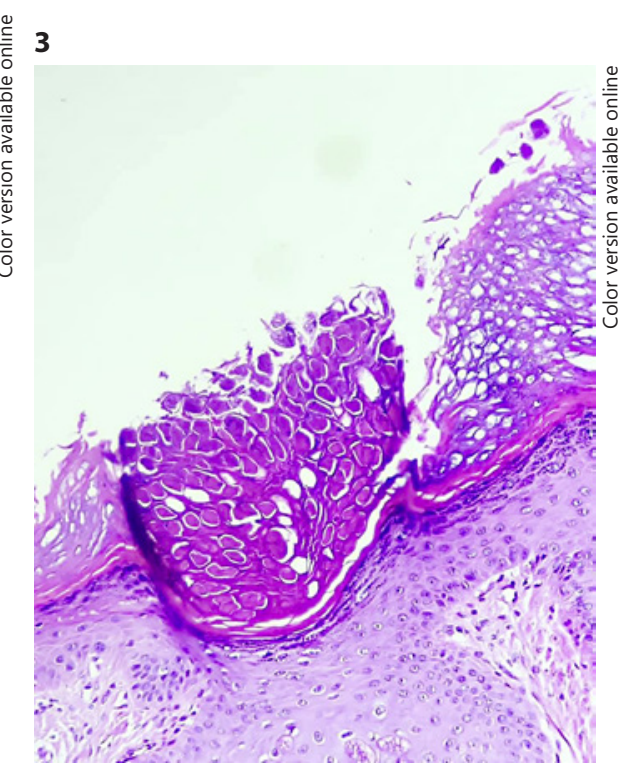

Fig. 2. Dermoscopy shows polylobular, roundish, white to yellow structures along with punctiform/dotted and serpentine vessels.

Fig. 3. Histopathological examination of the excision specimen showed numerous Henderson-Paterson bodies (intracytoplasmic hyaline eosinophilic inclusion bodies) confirming the diagnosis of MC.

\section{Case Report/Case Presentation}

A 24-year-old male having a painless subungual mass of 3 weeks duration on the great toe of his left foot was referred to us with a diagnosis of subungual wart. Physical examination revealed confluent pinkish papules on the hyponychium (Fig. 1a). The patient had no similar lesion elsewhere. Dermoscopic examination revealed polylobular, roundish, white to yellow structures along with punctiform/dotted and serpentine vessels (Fig. 2). Serological investigations including HIV and the venereal disease research laboratory test were within normal limits. The patient was treated with a total shave excision of the lesion followed by immediate cryotherapy. A preliminary diagnosis of MC, viral wart, and fibrokeratoma was made. Histopathological examination of the excision specimen showed numerous Henderson-Paterson bodies (intracytoplasmic hyaline eosinophilic inclusion bodies) confirming the diagnosis of MC (Fig. 3). The surgical procedure applied allowed complete removal of the lesion, and no recurrence was observed after 3 months (Fig. 1b). 


\section{Discussion}

MC is a common infectious skin disease which affects both genders and may occur in all age groups. It may present with single, multiple, or grouped lesions. MC is usually self-limiting in a period of 6-9 months in the majority of cases; however, in rare cases, it may persist for years. MC can affect any region; however, the lower abdomen, thighs, genitals, and perianal area are the sites most commonly involved [1]. Subungual MC is extremely rare, and only 1 case has been published in the literature. Başaran et al. [2] reported a case of MC localized on the hyponychium of the middle finger of the right hand in a young woman. Oral, ocular, and plantar regions are other unusual MC localizations reported [3-5].

MC may present atypically with giant, eczematous, and follicular lesions [6-8]. The atypical manifestations may strongly imitate many cutaneous conditions, including warts, basal cell carcinoma, intradermal nevus, keratoacanthoma, and amelanotic melanoma [6]. The diagnosis of MC may be a real challenge especially in HIV-infected individuals [9]. Other causes of immunosuppression may also lead to atypical presentations. Our patient had no history of systemic disease and immunosuppression. HIV serology was also negative.

Dermoscopy has recently been an indispensable part of dermatology practices. Dermoscopic features of molluscum are well described. Polylobular, roundish, white to yellow structures and peripheral crown vessels are characteristic dermoscopic findings [1]. Radial and punctiform vessels may also be seen [10]. In our case, we observed polylobular, roundish, white to yellow structures along with punctiform/dotted and serpentine vessels. The main differential diagnosis in our case was subungual wart, in which dermoscopy usually shows a lobulated surface with thrombosed capillaries giving a so-called frog spawn appearance [11]. Although dermoscopy is an important auxiliary diagnostic tool, the final diagnostic confirmation is always based on histopathological examination.

To the best of our knowledge, subungual MC localized on the toe has not been described before.

\section{Statement of Ethics}

A written informed consent was obtained from the patient for the publication of this case report and accompanying images. The authors have no ethical conflicts to disclose.

\section{Disclosure Statement}

The authors have no conflicts of interest to declare.

\section{Funding Sources}

There were no funding sources.

\section{Author Contributions}

Ömer Faruk Elmas: concepts, design, definition of intellectual content, literature search, data acquisition, and manuscript preparation.

Asuman Kilitçi: manuscript editing, manuscript review, literature search, and data acquisition.

\section{References}

1 Meza-Romero R, Navarrete-Dechent C, Downey C. Molluscum contagiosum: an update and review of new perspectives in etiology, diagnosis, and treatment. Clin Cosmet Investig Dermatol. 2019 May;12:373-81.

2 Başaran YK, Turan E, Keklik B, Tarini EZ. A painful subungual lesion with a surprising diagnosis: molluscum contagiosum. Indian J Dermatol Venereol Leprol. 2014 May-Jun; 80(3):278

3 de Carvalho $\mathrm{CH}$, de Andrade AL, de Oliveira DH, Lima E, da Silveira EJ, de Medeiros AM. Intraoral molluscum contagiosum in a young immunocompetent patient. Oral Surg Oral Med Oral Pathol Oral Radiol. 2012 Jul; 114(1):e57-60.
4 Mutalik SD, Rasal YD. Successful Use of Oral Acyclovir in Ophthalmic Molluscum Contagiosum. Indian Dermatol Online J. 2019 JulAug;10(4):456-9.

5 Bahalı AG, Su O, Ozkaya DB, Sallahoglu K, Yıldız P, Demirkesen C, et al. Plantar Molluscum Contagiosum in an Adult Patient. J Am Podiatr Med Assoc. 2016 May;106(3):235-6.

6 Uzuncakmak TK, Kuru BC, Zemheri EI, Zindanci I, Turkoglu Z, Kavala M. Isolated giant molluscum contagiosum mimicking epidermoid cyst. Dermatol Pract Concept. 2016 Jul;6(3):71-3.

7 Binkley GW, Deoreo GA, Johnson HH Jr. An eczematous reaction associated with molluscum contagiosum. AMA Arch Derm. 1956 Oct;74(4):344-8.
8 Ive FA. Follicular molluscum contagiosum Br J Dermatol. 1985 Oct;113(4):493-5.

9 Pérez-Díaz CE, Botero-García CA, Rodríguez MC, Faccini-Martínez AA, Calixto OJ, Benítez F, et al. Giant molluscum contagiosum in an HIV positive patient. Int J Infect Dis. 2015 Sep;38:153-5.

$10 \mathrm{Ku} \mathrm{SH}$, Cho EB, Park EJ, Kim KH, Kim KJ. Dermoscopic features of molluscum contagiosum based on white structures and their correlation with histopathological findings. Clin Exp Dermatol. 2015 Mar;40(2):208-10.

11 Aqil N, Nassiri A, Baybay H, Gallouj S, Sara E, Mernissi FZ. Warts under the dermoscope. SM Dermatolog J. 2019 Jun;5(1):1030. 